\title{
The Choice and Innovation of Chinese Housing Finance System
}

\author{
Yuqi Wang \\ Capital University of Economics and Business, Beijing, China, 100070
}

Keywords: Housing Finance System, Government Role, Financial Institution, Securitization

\begin{abstract}
The housing finance system is related to the establishment and development of the housing distribution system reform. It is an important supporting system measure of Chinese housing system reform. It is an important part of constructing the housing security system. After the exploration, formation, deepening and perfection of the four stages of development, Chinese housing finance system gradually mature has made remarkable achievements. But with the policy of housing finance and commercial housing finance two housing finance system mutual influence, coexistence and development, the current financial system model gradually show the object overlap, operating a single, lack of funds and other shortcomings, hinder the housing finance system to further improve. Therefore, under the current historical conditions, it emphasizes the leading position of the government in the reform of the housing finance system, plays the guiding role of the government in the development of the housing finance system, innovates the housing financial institution model, changes the single status of the housing financial institutions to achieve housing mortgage securitization in the housing finance system innovation and development of the basic program.
\end{abstract}

\section{Introduction}

Housing as daily necessities and everyone is closely related to the housing system in the field of little change will cause a wide range of social concern. Housing finance system as an important part of Chinese housing system framework, although the practice is not long, but the degree of social concern is very high. Since the reform and opening up, Chinese housing distribution system reform steadily, the real estate market from the beginning to mature to mature, housing finance system has also been gradually established and developed to improve. However, the current domestic scholars for Chinese housing finance system research is still focused on a specific problem on the analysis, the lack of comprehensive systematic research. This paper explores the path choice and development direction of Chinese housing finance system from the perspective of the formation and evolution of housing finance system in our country, and ensures that housing finance plays an important role in maintaining social stability and promoting economic development.

\section{The Practice of Chinese Housing Finance System}

Chinese housing finance is established with the beginning of the housing system reform, is accompanied by the formation of the real estate market, housing distribution from the welfare distribution system to the monetization of the distribution system and the gradual development of the housing system, every point of change will be Causing housing finance to make the appropriate adjustments. Since 1978, Chinese reform and opening up policy, Chinese economic system gradually changed from a planned economy to a market economy, housing system reform has experienced four stages of development and housing finance has also occurred four changes. 
The first stage is from 1978 to 1985. During this period, China began to implement reform and opening up policy, this stage is the exploration of housing reform period, but also the establishment of Chinese housing finance period. Since 1978, the domestic housing supply for the serious shortage of the problem, the state proposed to break the original government fully bear the housing construction work model, in some cities pilot housing supply by the government "unified system" system to the government and the Departments and units of the common burden of the model, and try to "three three" in the form of housing sales pilot. At the same time, in order to solve the "build" model under the government and various departments need to bear the source of housing construction funds and the state opened the commercial housing bank credit business. Since then, Chinese housing credit business officially launched, the housing finance system was established.

In the establishment stage of the housing finance system, because the original intention of the system design is to solve the shortage of funds for the construction of the government and the units, the payment of housing loans is only for the housing construction units, the use is also limited to the development of commodity housing, People's housing consumption loans, housing credit scale is small, the use of a narrow range. China Construction Bank as the only designated bank, monopoly of all the housing credit business, for the prevention and control of loan risk is very unfavorable. Not only that, in the early days of the establishment of the housing finance system, because the government and the units as the main body of housing construction, in the subjective understanding still remain in the stage of relying on financial revenue to build housing, the bank as a loan to the financial institutions failed to fundamentally Change the operating mechanism, is still in the passive administrative lending stage, the general residents of the housing consumption awareness has not yet formed, housing credit in the entire housing construction investment share is very small, the slow development of housing finance. Although it cannot completely change the status quo of the field of housing in China, but the transformation of ideas, the introduction of housing financial institutions, broaden the channels of funding sources to promote business change business strategy to promote personal change housing concept, to reduce the burden of national financial construction and eventually form a perfect The housing finance system laid a good foundation.

The second stage is from 1985 to 1993. This time due to the low rent of public housing, housing purchase is insufficient and housing sales reform resistance is great. The state adopts the idea of "rent subsidy", and the housing is allocated in real terms for the allocation of housing money, which promotes the sale of housing by raising the rent of the house. Housing reform system reform substantive start, with the supporting housing finance system is also formally formed. August 1988, the first national housing reform work conference issued a "urban urban phased implementation of the housing system reform implementation of the program," made it clear that the establishment of the housing reform process and the development of the real estate market to adapt to the housing finance System, housing finance should serve the overall idea of housing reform system reform, it is necessary to ensure the smooth implementation of policy business, but also give full play to the enthusiasm of financial institutions to operate independently to support the housing system reform and housing market construction. Under the guidance of this policy, China has set up a housing savings bank in three cities in Yantai, Bengbu and Tangshan, which is the first financial institution specializing in housing finance business. However, since the initial establishment of the housing savings bank is a regional organization, only in their respective jurisdictions to carry out housing construction financing, financing business, business coverage is narrow, can not reflect the advantages of policy housing finance. While the deposit interest rate is low, the operating characteristics of the drawbacks are not obvious is very obvious, the lack of market competitiveness and attractiveness, failed to bring economies of scale. 
May 1991, Shanghai in the country took the lead in the implementation of the housing provident fund system. In October the same year, the second national housing reform work conference held, affirmed the practice of Shanghai and called on the promotion in the country. Since then, China Construction Bank as a specialized in housing finance business organizations in various cities in the country set up specialized real estate credit sector, engaged in housing construction funds to raise funds for housing financing, credit business settlement business, involving housing finance of all aspects of the housing capital market model. [1]

The third stage is from 1994 to 1997. During this period, in order to improve the living conditions of residents to meet the growing housing needs of the residents, the state widely implemented housing provident fund system, the implementation of housing commercialization, socialization. The original policy of housing finance services gradually transformed into a commissioned nature of the financial business, the proportion of ordinary residential financing gradually increased, the types of housing financial products continue to introduce new, housing consumption loans growing scale. At this point, the Government to establish a housing financial market is no longer simply to raise funds for housing construction, but gradually shift to regulate the allocation of funds in the housing construction and consumption areas, to guide the optimal allocation of resources in different regions, commercial banks housing the focus of financial business is no longer limited to government or unit housing construction, but continue to expand the scope of individual housing consumption.

As of the end of 1997, large and medium-sized cities nationwide have established a housing provident fund system, a large number of public housing sales to bring the housing rate of self-improvement, greatly speeding up the pace of housing construction. Although this period of Chinese housing finance has entered a stage of rapid development, but the attendant problems are becoming more apparent. On the one hand, the housing credit business in our country is a new business, the government, banks and individuals are lack of adequate understanding and understanding, so when the individual housing consumption loans increased significantly, the government and commercial banks are unable to timely Risk giving enough attention. Due to the lack of research on the bank risk, the protection of capital liquidity and the security of long-term bonds, there is an inherent resistance to the sustainable development of the housing credit business developed in the context of the lack of mortgage guarantee institutions and the concentration of secondary market loans. On the other hand, commercial banks as a for-profit financial institutions, for the lack of profitability of housing facilities and related infrastructure construction enthusiasm is not high, can not actively into the perfect housing service financing business, not conducive to Long - term sustainable development of the housing market.

The fourth stage is from 1998 to the present. July 1998, the state issued a document clearly put forward in the second half of 1998 to stop the physical distribution of housing, housing system reform into the construction of the whole society housing security system framework of the new period. At the same time, the state also proposed to continue to implement the housing monetization on the basis of the focus on the housing secondary market training, the development of housing finance, housing finance system has entered a comprehensive development, and gradually improve the new stage. During this period, the government liberalized the institutional access restrictions on housing finance, and commercial banks with financial licenses were able to carry out housing credit operations. To carry out the housing finance business operators to expand rapidly, and promote the prosperity of the housing financial market, and thus promote the further strengthening of institutional management efforts. Housing finance business policy and commercial gradually unified housing consumption credit business into the high-speed expansion stage, the housing 
finance business competition from the policy business and commercial business competition between the housing finance institutions to the full competition.

Chinese housing finance business there are many reasons for the development of blowout. First, after many years of housing reform, the sale of existing public housing and improve the existing public rental rents have been saturated, but the residents of the housing demand is still increasing, the housing market supply and demand imbalance is more prominent. Commercial banks for the pursuit of profit maximization, optimize the asset allocation structure, and gradually adjust the proportion of real estate development financial investment competition will be introduced into the housing consumption. Secondly, with the gradual improvement of the housing financial market, the commercial banks give full play to their professional advantages, and constantly develop innovative financial products. Housing credit business not only includes individual housing provident fund loans, but also the development of housing commercial loans, housing portfolio loans, housing credit loans and other financial products, expanding the variety and use of loans. Third, the People's Bank of China to relax the control and regulation of housing credit business, to give commercial banks greater autonomy operation space, promote the competition between banks, is conducive to banks to improve service levels, broaden the scope of services.

Through the reform of Chinese housing finance system can be found, since the reform and opening up, along with the deepening of the housing distribution system reform, Chinese housing finance from scratch, from simple to complex, increasingly perfect. However, with the policy of housing finance business and commercial housing finance business continues to advance, the scale of housing consumption will expand, housing finance system in the hidden dangers will gradually appear. Therefore, it is necessary to analyze the existing institutional models and find out the problems within the framework of the system, which is to ensure the sustainable and healthy development of housing finance in China.

\section{The Problems and Constraints of Chinese Existing Housing Finance System}

After decades of development, China has formed the current housing finance system with commercial finance as the main form, policy finance and commercial financial interaction. This system model in both policy and commercial advantages at the same time, it is inevitable because of the combination of the two problems and contradictions.

First of all, due to the existence of policy housing finance and commercial housing finance in the service object and coverage overlap, resulting in a part of the crowd system supply surplus, while the other part of the crowd system supply is lacking, this situation is particularly serious in rural areas. [2] At present, China has not yet set up special institutional arrangements for the housing financial needs of rural residents. In the aspect of commercial finance, housing financial institutions have mainly served in urban residents. In terms of policy finance, the housing provident fund system has not covered rural residents, rural housing financial system arrangements for a long time blank, farmers housing finance needs cannot be met. When the land is owned by the farmer, the farmer has a policy and legal obstacle to the bank loan due to the inconsistency between the property and the land.

Second, the type of institutions engaged in housing finance business is single and the purpose of business is consistent, which is easy to cause the convergence of financial institutions. It is not conducive to the market segmentation. When the state finance and monetary policy fluctuate, it may also reduce the financial services inadequate supply or increased inter-agency vicious competition in financial services. The lack of housing financial intermediaries, the existing property insurance nature of the financial intermediaries are mostly low quality, small size, limited scope of business, 
the ability to resist risks is poor, the lack of market competitiveness, product design behind the housing finance business development speed, making the financial institutions in the housing finance business when the systemic risk is too concentrated, is not conducive to increasing the welfare of consumers.

Third, the housing finance business management of a single source of funds caused by a single, poor liquidity loans. Commercial banks as the main body of the housing finance business, the main source of funds is the bank's own funds, due to provident fund deposits and public housing restructuring after the sale of funds collected only limited to a limited number of large state-owned commercial banks dominate the use of most of the business Bank funding sources are limited, the size of funds is small. At present, the individual housing loans issued by various commercial banks usually have a longer repayment period. Even if there is a borrower's early repayment to reduce the useful life of the funds, it is necessary to wait until the repayment period ends to recover the funds completely. Relative to the growing demand for loans, individual housing loans are less liquid.

At present this situation is the result of many factors together, summed up mainly in the following points. First of all, Chinese housing finance system development stagnation, and the current socio-economic, political background has a close relationship. Although the reform of housing system in China has promoted the establishment and development of housing finance and played a huge role in promoting it in the early stage. With the deepening of reform, the resistance encountered gradually increased, and the reform of housing system slowed down. The speed of financial development and the lack of government functions exacerbated the problem. In the housing mortgage market, tax policy formulation, housing trade and loan legal protection, low-income people credit qualification guarantee and other functions need to be completed by the government, the government failed to assume the responsibility is to restrict the development of housing finance system.

Second, the information asymmetry increases the transaction costs of housing finance. Due to the single institution of housing finance business, the lack of intermediaries such as guarantee and assessment that can share the risk of transactions, commercial banks will improve the restrictions on applying for housing loans in order to avoid moral hazard. Under the condition of high house price and low income, the improvement of the loan application condition further limits the residents' ability to meet their own housing demand and restricts the development of housing finance in our country.

Third, the housing secondary market development is slow, maturity is not high. Housing secondary market as an individual will own housing to sell the place again is to increase the housing market supply, activate the housing market, to meet the needs of different income groups, to speed up the bank to recover the loan funds an important means. Therefore, with the deepening of the reform of the housing system, the commercialization of housing, the gradual increase of socialization, allow and encourage individuals to sell existing housing and provide corresponding legal assurance and policy support is the trend. In the old housing system, the housing allocation is unreasonable, the relative surplus of individual housing and the relative shortage of serious, to a certain extent, disrupted the housing market on the secondary market order, to combat the enthusiasm of the residents to buy, hinder the housing finance development.

\section{The Innovation and Development of Chinese Housing Finance System}

It is well known that the evolution of the system is inseparable from the socio-political and economic environment in which Chinese housing finance system is developed. The model also has its social background and historical objectivity. Therefore, it cannot be neglected when discussing 
the development direction of housing finance in China The social reality of our country. As a result of historical history and China from east to west, the first coastal inland reform policy, making Chinese different provinces and regions, the level of economic development between regions is far apart, so in the development of housing finance system to take into account the regional gap, the implementation of differences The financial system. On the other hand, Chinese large population inhabitants income inequality is very obvious. Residents' income is different and the demand for housing is not the same, which requires the Government to develop policies for different income groups to give the appropriate institutional arrangements, to be targeted. Not only that, Chinese fiscal revenue level is not enough to support the entire housing finance development. Although after several decades of market economy reform, Chinese national strength and living standards have greatly improved, but the state's financial capacity is still very limited, the need for government funding to complete the construction of social security is still a lot, so available The funds to solve the housing problem is very limited, relying solely on the government's revenue cannot solve the problem of civil housing. Only the implementation of the market-oriented housing financial system, through the financial market autonomy, to absorb private capital into the field of housing construction, the use of capital leverage leveraged the entire housing market, to meet the residents living needs. [3]

Specifically, Chinese housing finance system mainly has the following development direction. First of all, pay attention to the government in the housing finance system reform in the dominant position, and effectively play the government in the housing finance system in the development of the guiding role. At present, Chinese housing prices remain high, has been out of the scope of ordinary residents can not afford to strengthen the government's macro-control, relying on market behavior to adjust itself has been difficult to achieve the rational development of housing finance system. Therefore, the need to guide the housing prices through the government to reduce the residents relies on housing finance policy to obtain housing capacity. The government's policy guidance is mainly embodied in the formulation of appropriate policies to encourage and support the development of housing financial institutions and related intermediaries and the flexible use of fiscal and subsidy policies to improve the external political and economic environment for the development of the housing finance system.

At the same time, give full play to the functions of the government, but also should further increase the support of the housing provident fund system, play a policy of financial low-income people's housing security role. Housing provident fund system as the main form of housing policy finance in China, reform the organization, improve the efficiency of capital use, is to support low income housing buyers housing an important way. Specifically, it should establish a national provident fund linkage system, the introduction of cross-regional funds transfer payments and financing system to achieve the inter-regional liquidity of provident fund funds, thereby enhancing the efficiency of the use of provident fund funds. The use of innovative provident fund, consider the development of housing discount loans, housing subsidies and other forms, to expand the coverage of housing coverage of low - income people. In the protection of provident fund depositors of the initiative at the same time, better protection of the interests of low - income earners, maintaining social equity.

Secondly, to change the status quo of single housing financial institutions, innovative housing financial institutions model, to adapt to Chinese housing market commercialization, housing financing market demand for new. Chinese housing finance is accompanied by the housing system reform produced and grew up to the development of today has formed a policy of housing finance and commercial housing finance, including the two main parts of the institutional framework, so the 
corresponding institutional settings should also be abandoned The existing single institutional type of model, divided into public financial institutions and private financial institutions, respectively, the two systems were treated. For the public financial institutions, the government should be set up by the non-profit financial management institutions to coordinate, manage and allocate funds; for private financial institutions, you can completely deal with the rules of market management, give full play to the autonomy of the market initiative. Therefore, the idea of building a comprehensive housing financial institution system in our country should be that the government should establish a unified national non-profit housing financial institution, and pay attention to the establishment and development of the general commercial housing financial institutions and set up various forms of housing Loan guarantee and other services intermediary. According to this development ideas, the existing housing provident fund system in the future policy development should be more to the low-income groups tilt, focus on meeting the housing needs of low- and middle-income families. In the case of ordinary commercial financial institutions, we can consider introducing a more mature model of housing cooperatives in foreign countries. Through the government's policy support, we encourage residents to raise funds in cities and towns, especially small towns and rural areas, and absorb private capital into the housing construction market. Mobilize the enthusiasm of residents to participate in the same time to reduce the financial investment in housing construction pressure. In addition, it should also set up public or joint-stock institutions to provide housing loan guarantees and other services intermediaries. Loan guarantee service can improve the loan security of the loan issuer enhance its confidence in the issuance of loans, thereby increasing the possibility of home buyers to apply for housing loans to improve his loan amount. Faced with the current reality of Chinese income and housing prices gap is too large, the establishment of housing loan guarantee institutions to mobilize the enthusiasm of both sides have a catalytic role. At this stage, taking into account the constraints of corporate economic capacity can be based on public housing loan guarantee institutions, individual housing loans to provide security. With the increase in the size and number of housing loans and the development of the housing industry, and then gradually transformed into a general commercial housing asset guarantee intermediaries.

Third, the development of housing finance secondary market to achieve housing mortgage securitization. The state has introduced a series of policies to support the housing industry, which greatly promoted the process of monetary reform of housing distribution, housing finance and strong market demand and broad space for the implementation of housing mortgage securitization provides a good external politics economic environment. At the same time, the housing finance primary market that housing mortgage market after years of development has also established a basic market system, with the development of the secondary market objective conditions. Therefore, the implementation of mortgage securitization is to resolve the current housing mortgage problems encountered by the important means of solution. As the mortgage securitization is a wide range of financial projects, so the specific implementation should be phased, progressive. In the initial stage, the term structure of bonds and housing mortgages may not be required to be fully consistent with the repayment arrangement, and the bond credit is raised by way of mortgage guarantee, and the financing gap is made up through the financing of circulation. With the deepening of the degree of securitization, the establishment of specialized institutions to carry out the operation of mortgage loans, which really make the loan within the mortgage period to achieve the same flow of funds. Specific implementation, the housing finance market can be relatively perfect development, housing mortgage loans in the development of better large and medium-sized cities to carry out the first to be mature and then nationwide to promote the formation of a national housing finance secondary market. 
As the housing loan securitization is a financial innovation, so in the implementation of the relevant work to do a good job. The first thing to do is to set the standard for home mortgages, classify mortgages with similar properties, and provide available quantitative data for subsequent securitization work. After the mortgage securitization, the demand for real-time renewal of loan data has been greatly improved. Therefore, it is necessary to upgrade the system from the hardware facilities and the software system at the same time to realize the real-time update of the housing mortgage information. Third, establish and improve the legal system, to speed up the loan trust institutions and asset securitization of the legislative work, improve the loan collateral disposal process. Only the clear property rights, the real disposal of loan collateral, to ensure that the creditor's rights, can effectively guarantee the interests of mortgage investors, so as to ensure the sustainability of securities investment. Finally, the development of housing mortgage credit insurance. Chinese housing mortgage loan repayment period is long, the risk of lending, the implementation of securitization of the attraction is not strong, the introduction of credit insurance mechanism, the mortgage products to ensure that the risk can be effectively shared and transferred to encourage financial institutions to issue housing loans to promote mortgage securitization.

\section{References}

[1] Research on the Prevention and Control of Personal Housing Loan in Chinese Commercial Banks - Taking Construction Bank as an Example [D], Southwest University of Finance and Economics, 2014.

[2] Xie Feiyuan. Rural financial model development selection research [J], modern business, 2012 (18), 89.

[3] Liu Weipeng. On Chinese housing finance model selection thinking [J], China Housing Finance, 2000 (2), 48-49 